Trifoliellum bioblitzii, a new genus of trichomycete from mayfly nymphs in Nova Scotia, Canada

Author(s): D.B. Strongman and Merlin M. White

Source: Mycologia, Vol. 103, No. 1 (January/February 2011), pp. 219-225

Published by: Mycological Society of America

Stable URL: http://www.jstor.org/stable/27920479

Accessed: 17-06-2015 12:12 UTC

\title{
REFERENCES
}

Linked references are available on JSTOR for this article:

http://www.jstor.org/stable/27920479?seq=1\&cid=pdf-reference\#references_tab_contents

You may need to $\log$ in to JSTOR to access the linked references.

Your use of the JSTOR archive indicates your acceptance of the Terms \& Conditions of Use, available at http://www.jstor.org/page/ info/about/policies/terms.jsp

JSTOR is a not-for-profit service that helps scholars, researchers, and students discover, use, and build upon a wide range of content in a trusted digital archive. We use information technology and tools to increase productivity and facilitate new forms of scholarship. For more information about JSTOR, please contact support@jstor.org. 


\section{Trifoliellum bioblitzii, a new genus of trichomycete from mayfly nymphs in Nova Scotia, Canada}

\author{
D.B. Strongman ${ }^{1}$ \\ Department of Biology, Saint Mary's University, \\ Halifax, Nova Scotia, Canada B3H 3 C3 \\ Merlin M. White \\ Department of Biological Sciences, Boise State \\ University, 1910 University Drive, Boise, Idaho \\ 83725-1515
}

\begin{abstract}
Trichomycetes are an ecological group of fungi and protists that colonize the gut lining of invertebrates in aquatic and moist terrestrial habitats. The diversity of this group appears to be high with many new species discovered each year. A new genus of fungal trichomycete, Trifoliellum (Harpellales), is described here with the type species $T$. bioblitzii. This genus is characterized by having unique, trefoilshaped asexual spores (trichospores). Another new species, Legeriosimilis halifaxensis, also is described from the same mayfly host, Eurylophella temporalis, collected from the same site near Halifax, Nova Scotia.
\end{abstract}

Key words: aquatic insects, endobionts, gut fungi, Kickxellomycotina, Zygomycota

\section{INTRODUCTION}

A bioblitz can be a $24 \mathrm{~h}$ taxonomic survey of all organisms in a defined area, such as a park or other green space usually located in a town or city, or a more extensive survey in other areas where biodiversity is of interest. One of the purposes of these events is to introduce the public to the diversity of living things in their immediate vicinity. A description of the parameters typically included and organizational details for a bioblitz can be found at http://web. uconn.edu/mnh/bioblitz/. Whereas the aim of a bioblitz is not normally to find new organisms, any time groups of taxonomists survey an area interesting and sometimes unexpected discoveries are made. It is not uncommon for press releases post bioblitzes to include new geographic records, sightings of rare species and other taxonomically noteworthy reports (see UCONN 2010, National Geographic 2010).

As part of the Saint Mary's University Bioblitz 5-6 Jun 2009 in Halifax, Nova Scotia (NS), we collected

Submitted 15 Jun 2010; accepted for publication 23 Jul 2010.

${ }^{1}$ Corresponding author. E-mail: doug.strongman@smu.ca aquatic insect and other arthropod species that are suitable hosts for trichomycetes, fungi and protists that form an ecological community in the intestinal tract (Lichtwardt et al. 2001). We found several species of fungi belonging to the Harpellales as well as protist species commonly found in this cryptic, highly specialized niche, specifically the arthropod gut. Included in our collections was a trichomycete fungus that had asexual spores (trichospores) unlike any other species in the order, so a new genus, Trifoliellum, was constructed with the type species $T$. bioblitzii. We also describe another new species, Legeriosimilis halifaxensis, from collections of mayflies from Kearney Lake in Halifax. There are limited published records of trichomycetes from Nova Scotia (Strongman 2005, Strongman and White 2006) so the taxa described here add to the baseline inventory of gut-inhabiting trichomycetes from this eastern province.

\section{MATERIALS AND METHODS}

The first collections of insects from Kearney Lake were made 5 Jun 2009 in front of the Maskwa Aquatic Club (MASK, $44^{\circ} 41^{\prime} 33^{\prime \prime} \mathrm{N}, 63^{\circ} 41^{\prime} 38^{\prime \prime} \mathrm{W}, 72 \mathrm{~m}$ ) as part of Saint Mary's Bioblitz in the Blue Mountain-Birch Cove Lake Wilderness Area, a newly designated protected area near Halifax, NS. Samples were also taken from a site near the MASK site, (MASK1, 44 $41^{\prime} 38^{\prime \prime} \mathrm{N}, 63^{\circ} 41^{\prime} 50^{\prime \prime} \mathrm{W}, 56 \mathrm{~m}$ ) 24, 29 Jun 2009 and 1, 3, 7, 13 Jul 2009 as well at a second site on the opposite side of the lake (KRL, $44^{\circ} 41^{\prime} 41^{\prime \prime} \mathrm{N}, 63^{\circ} 41^{\prime} 34^{\prime \prime} \mathrm{W}$, $36 \mathrm{~m}$ ) in front of the Lebanese Cultural Centre 18, 22, 24 Jun 2009. Mayfly nymphs, Eurylophella temporalis McDunnough, collected during the bioblitz had unusual harpellid fungal trichomycetes in the hindgut, so subsequent collecting focused on retrieving as many individuals of this host as possible to provide more morphometric data on these fungi. A final sample from MASK1 29 Sep 2009 yielded no specimens of the mayfly host. Collections of $E$. temporalis nymphs on 31 May 2010 and 8, 14 Jun 2010 had both new species in the hindgut. Other hosts examined for trichomycetes included mayflies (Leptophlebiidae) and midge larvae (Chironomidae) collected from the lake in June and July, as well as terrestrial isopods (pill bugs) collected 5 Jun 2009.

Immature stages of aquatic insects were collected with an aquatic dip net (30 cm gape, $0.5 \mathrm{~mm}$ mesh) by disturbing the substrate with our feet (kick-sampling) and capturing the dislodged hosts in the net. Terrestrial pill bugs were collected by hand from the ground. Guts were dissected in drops of water in glass Petri plates on the stage of a stereomicroscope equipped with a transmitted light source. The 
insect gut was removed with fine-tipped forceps and transferred to water on a microscope slide (wet mount) where microscopic thalli were teased out with insect pins mounted in pin vises (Grobet USA). Spores and other taxonomically significant characteristics were observed with a compound microscope equipped with phase and differential interference contrast (Nomarski) optics. Semipermanent voucher slides were made by infiltrating specimens with a drop of lactophenol cotton blue stain $(200 \mathrm{~g}$ phenol, $0.5 \mathrm{~g}$ cotton blue stain, $400 \mathrm{~mL}$ glycerol, $200 \mathrm{~mL}$ lactic acid and $200 \mathrm{~mL}$ distilled water) placed on the edge of the cover slip. After removing excess stain, the edges of the cover slip were sealed with clear fingernail polish (Lichtwardt 1986, Lichtwardt et al. 2001). Digital images were taken from both living (wet mounts) and stained voucher specimens. Some species were identified with the LUCID keys for trichomycetes available at the University of Kansas Website (Lichtwardt 2004). Type specimens for both new species are deposited at the National Mycological Herbarium, Agriculture and Agrifoods Canada, Ottawa, Ontario (DAOM). Additional voucher specimens of the new taxa, as well as other species reported, are available from the authors. Intact host vouchers are deposited at the Canadian National Collection of insects, arachnids and nematodes, Ottawa.

\section{RESULTS}

A new genus of fungal trichomycete was recovered from the hindgut of mayfly (E. temporalis) nymphs collected as part of the 2009 Saint Mary's Bioblitz, as well as another new species co-occurring in the hindgut of the mayfly host, and both are described here.

\section{TAXONOMY}

Trifoliellum gen. nov. Strongman \& M.M. White

Thallus axe centrali, ad parietem interiorem proctodaei cellula basali tumida et materia secreta affixus, interdum in caespitibus densis a cellulis basalibus aggregatis; verticillatim ramosus, trichosporis in apicibus ramulorum fertilium portatis. Trichosporae maturae complanatae et leviter trilobatae ubi ad thallum affixae, trifolioideae ubi liberatae, 2 vel 3 appendicibus instructae, sine collo. Zygosporae ignotae. Proctodaeum Ephemeropterarum incolens.

Thallus with a central axis, verticillate branching, attached to the hindgut lining by a swollen basal cell and secreted material; thalli sometimes in dense clusters with aggregated basal cells. Trichospores produced on the tips of thin fertile branchlets, at maturity flattened and slightly trilobate when attached to the thallus, trefoil-shaped when released, with two or three appendages and no collar. Zygospores unknown. Attached to the hindgut of mayflies (Ephemeroptera).

Type species. Trifoliellum bioblitzii.
Etymology. From the Latin trifolium in reference to the trefoil leaf-like shape of the trichospores.

Trifoliellum bioblitzii Strongman \& M.M. White sp. nov. FIGS. 1-9

Mycobank MB518537

Cellulae axis centralis thalli 4-9 $\mu \mathrm{m}$ latae (FIGs. 2, 3); cellula hapteroidea basalis $8-10 \mu \mathrm{m}$ diam (Figs. 4, 5); ramuli verticillati fertiles ad 1.5-2 $\mu \mathrm{m}$ lati angustati, trichosporis 4-16 secundis (FIGS. 1, 7). Trichosporae base brevi angustata affixae (FIGS. 1, 7), juventute ovoideae, in maturitate ante liberationem prominentia utroque latere evoluta, sic trifolioideae (FIGS. 1, 6, 7, 8), 2 vel 3 appendices tenues ferentes, sine collo (Figs. 6, 8, 9). Zygosporae ignotae. Thallus ad proctodaeum nympharum Ephemerellidarum affixus.

Holdfast basal cell 8-10 $\mu \mathrm{m}$ diam (FIGS. 4, 5), cells of the central axis of the thallus $4-9 \mu \mathrm{m}$ wide (FIGs. 2, 3 ), trichospore-bearing branchlets narrowing to 1.5$2.5 \mu \mathrm{m}$ wide with 4-16 trichospores produced along one side of a branchlet (FIGS. 1, 7). Trichospores attached by a short $(<1 \mu \mathrm{m})$ tapered base (FIGS. 1, 7); young spores are ovoid but when mature, before release, they develop a protrusion on two sides giving a trifoliate-leaf shape (FIGS. 1, 6, 7, 8). Trichospores have two, or more commonly, three thin appendages (FIGS. 6, 8, 9) and no collar. Zygospores unknown. Attached to the hindgut of mayfly (Ephemerellidae) nymphs.

Etymology. Because the fungus was discovered as part of the 2009 Saint Mary's University Bioblitz we acknowledge this event as the source of its discovery.

Specimens examined. CANADA. NOVA SCOTIA: Kearney Lake, west of Maskwa Aquatic Club (MASK1). Lactophenol cotton blue-stained slide prepared from the hindgut of a mayfly nymph (E. temporalis) collected 24 Jun 2009 (HOLOTYPE DAOM 240998). Additional specimens, similarly stained on glass microscope slides, collected at MASK1 29 Jun 2009 and 1, 3, 7, 13 Jul 2009. Also mayfly nymphs from the lake, north of Maskwa Aquatic Club off Kearney Lake Road across from the Lebanese Cultural Centre (KRL) collected 18, 22, 24 Jun 2009. Collections of the same host on 5 Jun 2009 from Kearney Lake in front of Maskwa Aquatic club (MASK). Collections of the same host from MASK1 on 31 May 2010 and 8, 14 Jun 2010.

Commentary. The thallus structure and the swollen basal cell in $T$. bioblitzii are similar to Gauthieromyces spp. and Graminella spp., also known from mayflies (Lichtwardt 2004). The trichospores of $T$. bioblitzii are also tiny, like the spores of the species in these two genera. However no described species of trichomycete to date has the trefoil-shaped trichospores with 2-3 appendages seen in $T$. bioblitzii. Other harpellids associated with mayfly nymphs have trichospores with 2-3 appendages, for example Ephemerellomyces, Legeriomyces, Legeriosimilis and Glotzia (Lichtwardt 2004), 


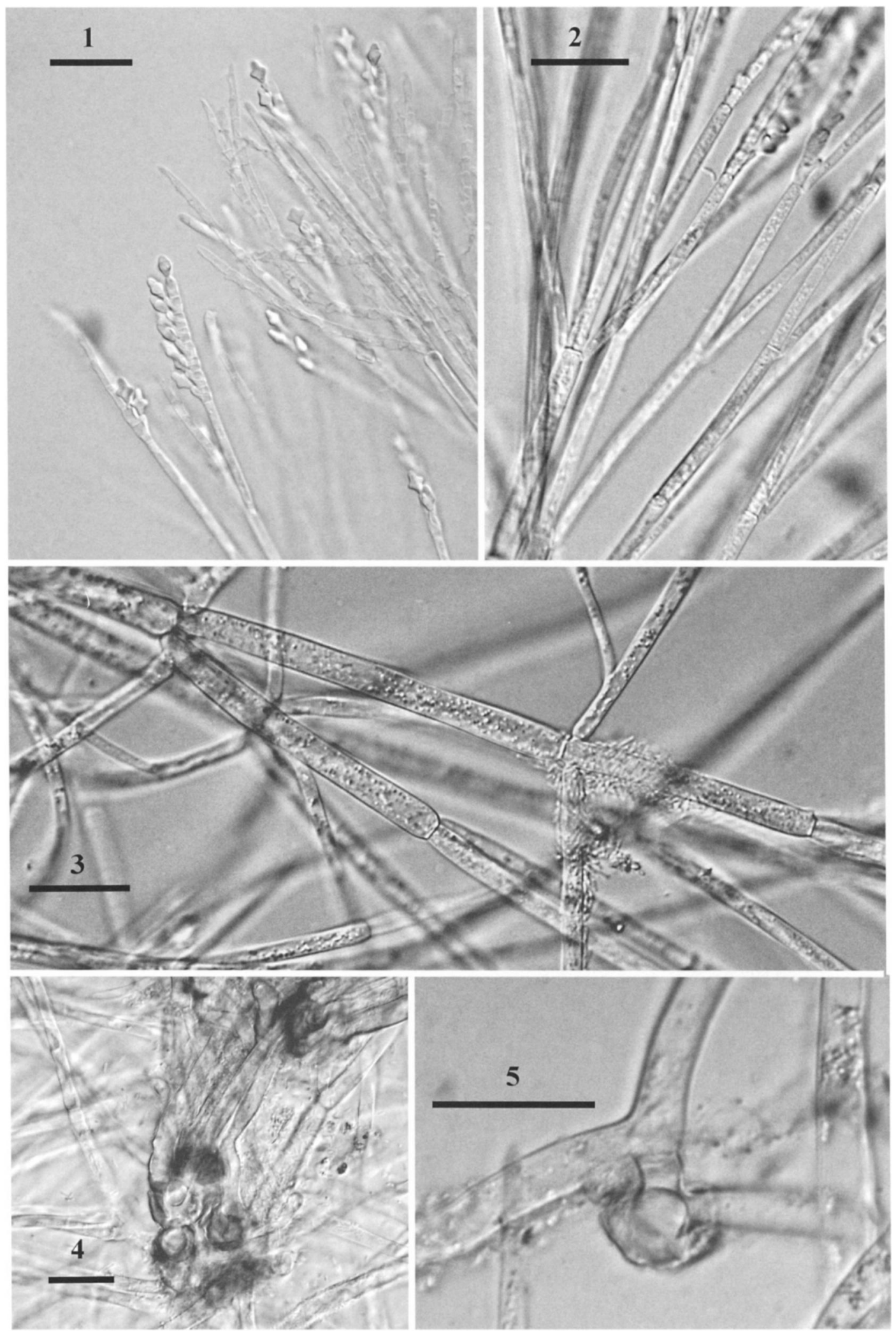

Figs. 1-5. Trifoliellum bioblitzii thallus characteristics. 1. Thallus with trichospores on fertile terminal branchlets. 2 , 3 . Verticilliate branching of the thallus. 4, 5. Bulbous basal cells with secreted material. Bars $=20 \mu \mathrm{m}$. 


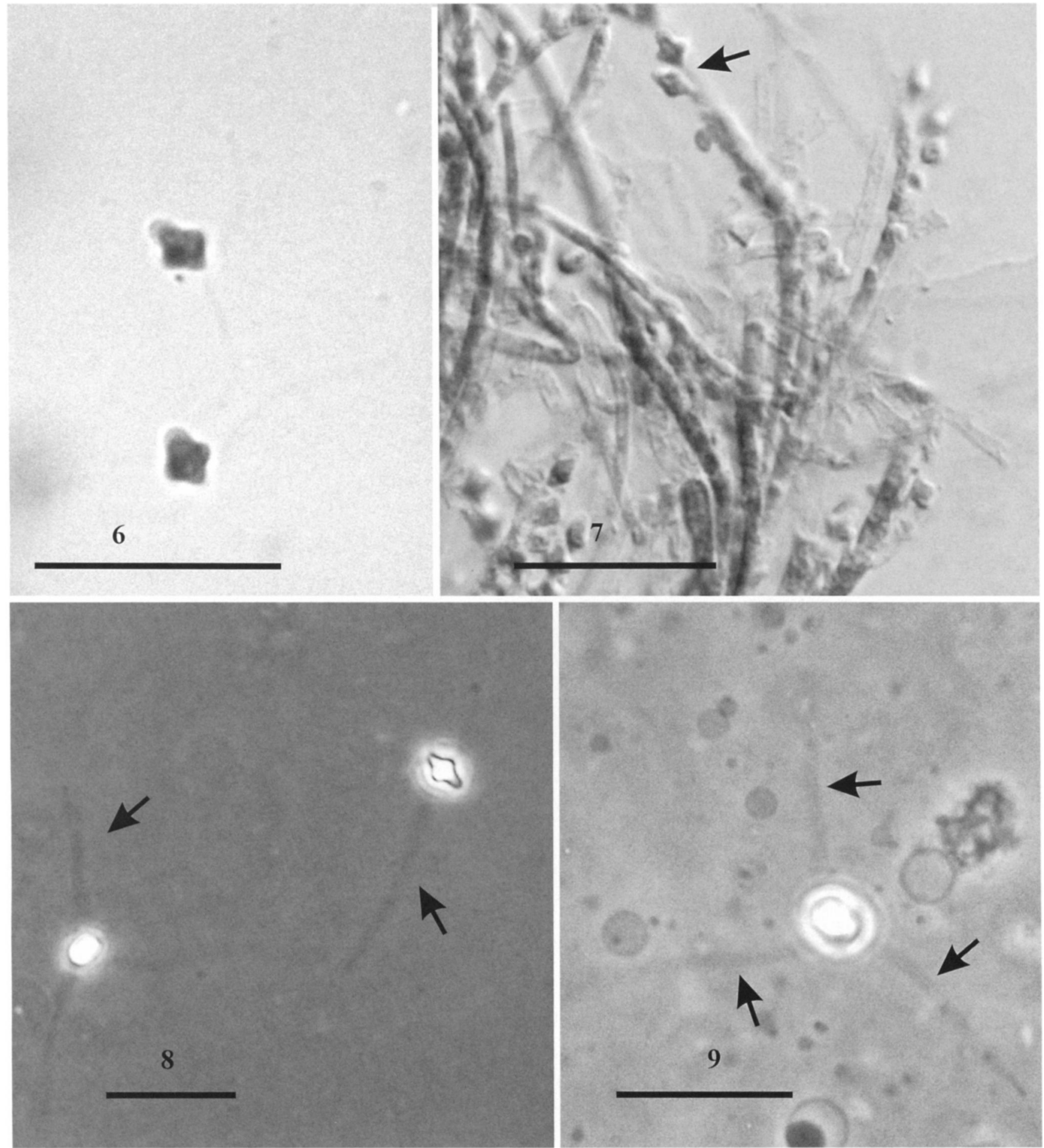

FIGS. 6-9. Trifoliellum bioblitzii trichospore characteristics. 6, 8, 9. Detached trichospores with appendages (arrows). 7. Trifoliate, leaf-shaped trichospores attached to fertile branchlets (arrow). Bars $=20 \mu \mathrm{m}$. 

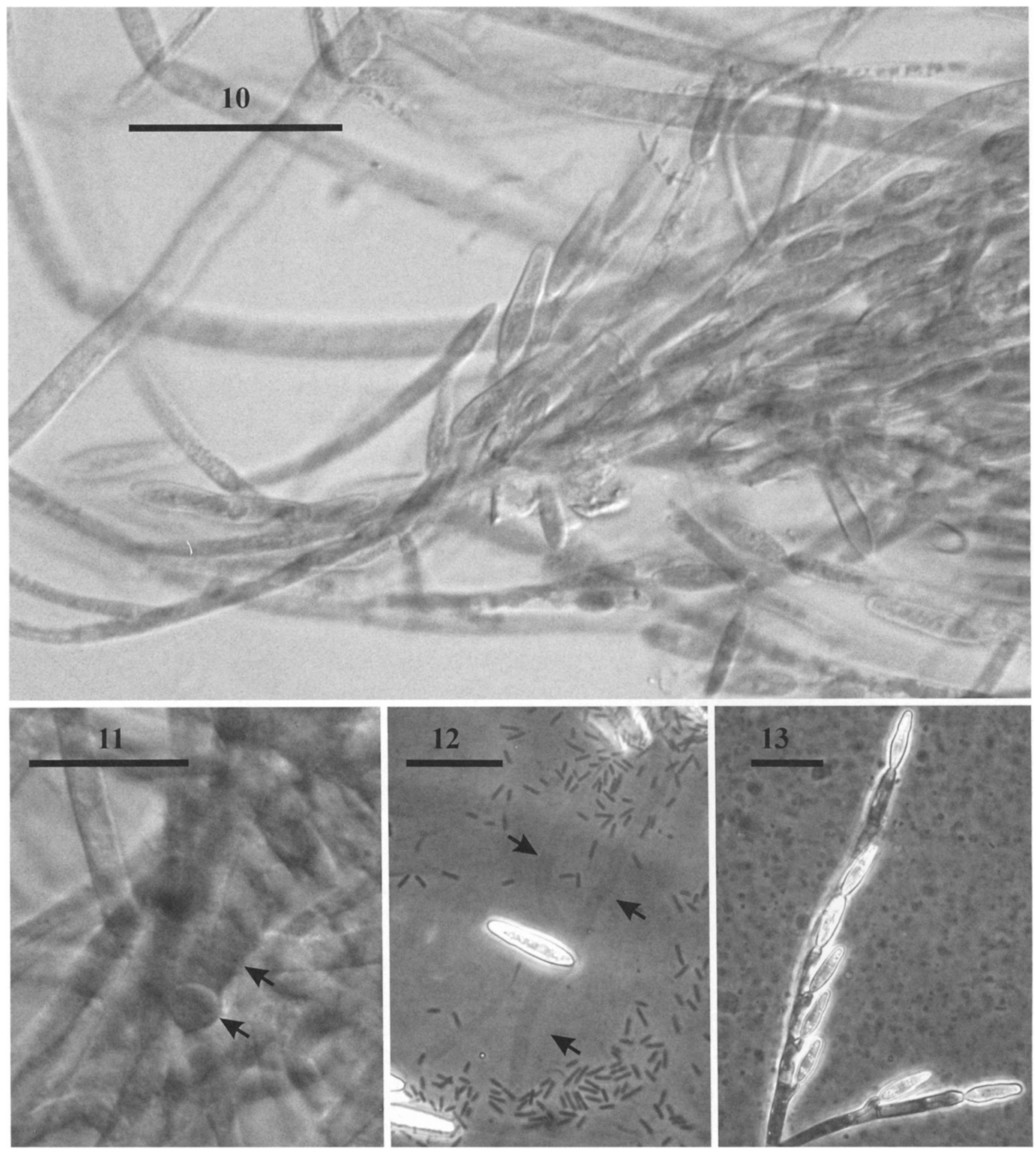

Figs. 10-13. Legeriosimilis halifaxensis. 10. Branched thallus with obpyriform trichospores attached. 11. Stout basal cell with disk-like holdfast (arrows). 12. Released trichospore with three thick appendages (arrows). 13. Trichospores attached to generative cells of fertile terminal branchlets. Bars $=20 \mu \mathrm{m}$. 
but these have larger spores and none have the trefoilshaped trichospores seen in $T$. bioblitzii.

\section{Legeriosimilis halifaxensis Strongman \& M.M. White} sp. nov.

Figs. 10-13

Mycobank MB518538

Thallus dense ramosus (FIG. 10), cellula basali elongata crassa $(5-10 \mu \mathrm{m})$ interdum bulbosa ad parietem interiorem proctodaei haptero discoideo affixa (FIG. 11). Trichosporae obpyriformes, (12-) 16.5-22 $\mu \mathrm{m}$ longae, infra medium 3.5$5 \mu \mathrm{m}$ latae, ad 2-3.5 $\mu \mathrm{m}$ proxime infra apicem rotundatum angustatae, appendices crassas 3 ad apices angustatas ferentes (FIG. 12). Trichosporae in ramulis terminalibus portatae, 2-8 in quoque ramulo fertili (FIG. 13). Zygosporae ignotae. Ad proctodaeum nympharum Ephemerellidarum affixus.

Densely branched thallus (FIG. 10) with a thick (5$10 \mu \mathrm{m})$, sometimes bulbous, elongated basal cell attached to the hindgut lining by a disk-like holdfast (FIG. 11). Trichospores obpyriform, (12-) 16.5-22 $\mu \mathrm{m}$ long, 3.5-5 $\mu \mathrm{m}$ wide below midline, tapering to 2$3.5 \mu \mathrm{m}$ just behind the rounded apex, with three thick appendages tapering at the tips (FIG. 12). Trichospores borne on terminal branchlets, 2-8 per branchlet (FIG. 13). Zygospores unknown. Attached to the hindgut of mayfly nymphs (Ephemerellidae).

Etymology. Referring to the city of the type locality, Halifax, Nova Scotia, Canada.

Specimens examined. CANADA. NOVA SCOTIA: Kearney Lake, west of the Maskwa Aquatic Club (MASK1). Lactophenol cotton blue-stained specimen from the hindgut of a mayfly (E. temporalis) collected 24 Jun 2009 (HOLOTYPE DAOM 240999). The type slide shows trichospores and appendages and also has thalli of $T$. bioblitzii and Paramoebidium spp. Slide MASK1-2 collected from the lake 8 Jun 2010 (PARATYPE DAOM 241000) contains thalli with attached trichospores. Kearney Lake, in front of Maskwa Aquatic Club (MASK), similarly stained specimens collected 5, 24 Jun 2009. Collections from MASK1 on 31 May 2010 and 8, 14 June 2010.

Commentary. This species has elongated trichospores, wider below the midline and tapered at the tip and with three basal appendages, placing it in genus Legeriosimilis. The spores of L. halifaxensis are shorter than all five described species, L. europaeus M.M. White \& Lichtw., L. leptocerci M.M. White \& Strongman, L. tricaudata M.C. Williams, Lichtw., M.M. White \& Misra, L. whitneyi Strongman \& M.M. White, and L. elegans Strongman, Juan Wang \& S.Q. Xu (Lichtwardt 2004, Strongman et al. 2010). Trichospores of $L$. whitneyi overlap in width with $L$. halifaxensis, but the shorter trichospores distinguish it from L. whitneyi. Ephemerellomyces aquilonius M.M. White and Lichtw. has similarly shaped trichospores but with either two or three appendages. In $E$. aquilonius the sporangiospore extrudes and attaches to the hindgut of the host then a single elongated fertile cell with one terminal trichospore is produced, which distinguishes this genus from others with similar trichospore characteristics (White and Lichtwardt 2004). These structures were not seen in L. halifaxensis.

Other species.-Other arthropods were collected and examined for the presence of trichomycetes. Midge larvae (Chironomidae) collected from Kearney Lake contained Stachylina grandispora Lichtw. and Stachylina nana Lichtw. A species of Parataeniella (possibly dilatata) was dissected from a pill bug. Mayflies (Ephemerellidae, Letophlebiidae) had Paramoebidium spp. in the hindgut. These species are common in their respective hosts wherever they are found (Lichtwardt et al. 2001).

\section{DISCUSSION}

The trefoil shape of the trichospores in $T$. bioblitzii (FIGS. 6-8) is unusual, and in the initial stages of development they resemble the ovoid trichospores of other small-spored species such as Graminella microspora S.T. Moss \& Lichtw. (Lichtwardt 2004). However as the trichospores of $T$. bioblitzii mature two protrusions form on opposite sides of the trichospore, producing the trefoil that is diagnostic for $T$. bioblitzii.

The mayfly host (Eurylophella temporalis) is common in streams (Merritt and Cummings 1996). Trichomycete fungi, such as Legeriosimilis whitneyi, Legeriomyces minae Strongman and Spartiella sp., are associated with nymphs of this species in collections from Ontario (Strongman and White 2008), Prince Edward Island (PEI) (Strongman 2007) and Nova Scotia (unpubl). Strongman (2007) described $L$. minae in E. temporalis from PEI and another Ephemerellid mayfly and suggested that the fungus might show some site specificity based on the widespread distribution of the hosts in PEI and elsewhere but with $L$. minae having a narrow distribution (one site) in PEI. Trifoliellum bioblitzii was collected only from $E$. temporalis in Kearney Lake, although the host has been recovered in stream habitats at many other sites in Nova Scotia, so the fungus might be restricted in its general distribution or it might be found only in lentic habitats. Both $T$. bioblitzii and L. halifaxensis frequently were found together in the same host gut but they also occurred separately in other host specimens. Legeriosimilis halifaxensis was collected from mayflies in Kearney Lake on the first collection date ( 5 Jun 2009) but was absent from collections after 29 Jun 2009 so it might have a different temporal distribution than $T$. bioblitzii. 
The mayfly host and $T$. bioblitzii were collected regularly from Kearney Lake from 5 Jun 2009 to $13 \mathrm{Jul}$ 2009 , but a collection from the MASK1 site on $29 \mathrm{Sep}$ 2009 yielded no $E$. temporalis nymphs. The $13 \mathrm{Jul} 2009$ collections had large masses of thalli with most of the spores released, but no sexual reproductive structures (conjugation or zygospores) were seen. Further collections are warranted in search of the sexual stage of both these new species. The unusual trichospores in $T$. bioblitzii make this species unique, but zygospores, if produced, might reveal affinities to other harpellids. Four of the five described species of Legeriosimilis have a known sexual stage (Lichtwardt 2004) so the probalility is high that $L$. halifaxensis also produces zygospores. Other species, such as Lancisporomyces spp in stoneflies and Legeriomyces minae in mayflies, that have been collected over several years from the same sites in eastern Canada (Strongman and White 2006, Strongman 2007) have shown a short, consistent time in the developmental cycle of the host when the sexual spores form; so continued, frequent collection of the mayfly host for L. halifaxensis might yield zygospores.

\section{ACKNIOWLEDGMENTS}

The authors thank the organizers and staff of Saint Mary's University Bioblitz 2009 for providing the logistical support for this work during the event. We gratefully acknowledge that our ongoing collahorative research on gut fungi has been greatly enhanced with recent and current support from NSF Awards DEB-0344''22 and DEB-0918182. We thank Carolyn Bird, Chester Basin, Nova Scotia, who provided the Latin translations and excellent editorial suggestions. We also appreciate the assistance of Dr Murray Colbo, Biology Department, Memorial University of Newfoundland who collected and identified some of the mayflies.

\section{LITERATURE CITED}

Lichtwardt RW. 1986. The Trichomycetes: fungal associates of arthropods. New York: Springer-Verlag. $343 \mathrm{p}$.

2004. Lucid keys to the Trichomycetes. http://www. nhm.ku.edu/ fungi/Lucid Keys.html (accessed 14 Jul 2010).

—, Cafaro M, White MM. 2001. The Trichomycetes: fungal associates of arthropods. http://www.nhm.ku. edu/ fungi/Monograph/Text/Mono.htm. (accessed 14 Jul 2010).

Merritt RW, Cummins KW. 1996. An introduction to the aquatic insects of North America. 3rd ed. Dubuque, Iowa: Kendall/Hunt Pubishing Co.

National Geographic. 2010. Website URL: http://www. nationalgeographic.com/field/projects/bioblitz. html). (accessed 8 Jun 2010)

Strongman DB. 2005. Synonymy of Ejectosporus magnus and Simuliomyces spica, and a new species, Ejectosporus trisporus, from winter-emerging stoneflies. Mycologia 97:552-561, doi:10.3852/mycologia.97.2.552

. 2007. Trichomycetes in aquatic insects from Prince Edward Island, Canada. Can J Bot 83:949-963.

—, Wang J, Xu SQ. 2010. New trichomycetes from western China. Mycologia 102:174-184, doi:10.3852/ 09-029

- White MM. 2006. New species of Lancisporomyces, Orphella and Paramoebidium, endosymbionts of stonefly nymphs from streams in Nova Scotia, Canada. Can J Bot 84:1478-1495, doi:10.1139/B06-107

- 2008. Trichomycetes from lentic and lotic aquatic habitats in Ontario, Canada. Botany 86:14491466, doi:10.1139/B08-107

UCONN. 2010. University of Connecticut/Museum of Natural History Website URL: http://web.uconn.edu/ mnh/bioblitz. (accessed 8 Jun 2010)

White MM, Lichtwardt RW. 2004. Fungal symbionts (Harpellales) in Norwegian aquatic insect larvae. Mycologia 96:891-910, doi:10.2307/3762122 